\title{
ANALISIS PENGARUH TATA KELOLA PERUSAHAAN TERHADAP STRUKTUR MODAL DENGAN KUALITAS LAPORAN KEUANGAN SEBAGAI MEDIATOR PADA PERUSAHAAN YANG TERDAFTAR DI BURSA EFEK INDONESIA
}

\author{
Johny Budiman \\ Helena \\ Universitas Internasional Batam \\ Email: johnybdmn@gmail.com
}

Submitted: Feb 14, 2017; Reviewed: Feb 15, 2017; Accepted: Mar 12, 2017

\begin{abstract}
This study aims to determine the effect of corporate governance on the capital structure with the quality of the financial reports as a mediator. Independent variables used in this research is the size of the board, independent board composition, concentration of ownership and managerial ownership. As a control variable is profitability and quality of the financial reports as a mediating variable. Thecapital structure is measured by the debt ratio. Samples from this study were 217 companies listed on the Indonesia Stock Exchange in the period 2011-2015 and were selected using purposive sampling method. Data have been obtained will be tested with mulitiple linear regressios with SPSS version 21.0. The results of this study indicate that there is a significant influence between board composition, concentration of ownership and managerial ownership on capital structure mediated by financial report quality.
\end{abstract}

Keywords: Capital Structure; Corporate Governance; Debt Ratio; Quality of Financial Reporting

\section{PENDAHULUAN}

Di era globalisasi ini, dapat dilihat bahwa perkembangan bisnis yang sangat pesat menimbulkan persaingan yang kompetitif dalam dunia usaha. Persaingan dalam bisnis ini memicu perusahaan untuk mengambil keputusan permodalan secara efisien dan efektif. Keputusan yang diambil oleh perusahaan dalam pemilihan sumber modal harus dipertimbangkan secara teliti sifat dan biaya karena setiap sumber modal tersebut memiliki efek finansial yang berbeda untuk menghasilkan struktur modal yang optimal bagi perusahaan. Masalah struktur modal merupakan salah satu hal penting bagi perusahaan, karena akan memberikan dampak secara langsung terhadap finansial perusahaan. Kesalahan dalam menentukan struktur modal akan meningkatkan risiko finansial seperti beban yang semakin besar, tidak dapat membayar beban bunga dan angsuran hutang.
Struktur modal yang efektif mampu mencerminkan perusahaan dengan keuangan yang kuat dan stabil. Oleh sebab itu, struktur modal telah menjadi salah satu faktor pertimbangan yang cukup penting. Ketika perusahaan mengeluarkan saham, maka perusahaan akan dihadapkan pada masalah besarnya biaya modal pengeluaran saham tersebut. Sedangkan ketika perusahaan melakukan pinjaman, biaya yang dikeluarkan mungkin lebih sedikit, namun terdapat risiko kewajiban dan pembayaran bunga yang meningkat (Sumbramanyam \& Wild, 2010)

Salah satu faktor yang mempengaruhi struktur modal adalah tata kelola perusahaan. Tata kelola perusahaan merupakan suatu sistem pengendalian internal perusahaan yang memiliki tujuan utama mengelola risiko yang signifikan guna memenuhi tujuan bisnisnya melalui pengamanan aset perusahaan dan meningkatkan 
nilai investasi pemegang saham dalam jangka panjang. Tata kelola yang berkualitas tinggi akan meningkatkan kinerja perusahaan tidak hanya dengan membangun dan mempertahankan budaya perusahaan yang memotivasi manajemen untuk mengambil tindakan-tindakan yang memaksimalkan kekayaan pemegang saham, tetapi juga dengan mengurangi biaya modal (Sheikh \& Wang, 2012).

Keberhasilan dalam pemilihan serta penggunaan modal merupakan suatu elemen kunci dari strategi finansial perusahaan (Velnampy \& Niresh, 2012). Hal ini memicu perusahaan untuk berusaha mengambil kebijakan praktik struktur modal yang optimal. Stretcher \& Johnson (2011) menyebutkan bahwa terdapat beberapa gagasan yang dapat membentuk dasar kebijakan praktik struktur modal. Sistem tata kelola perusahaan mengarah kepada kumpulan peraturan dan dorongan yang digunakan pihak manajemen untuk mengarahkan dan mengawasi jalannya kegiatan perusahaan. Oleh sebab itu, tata kelola perusahaan yang baik dapat memberikan dampak positif bagi perusahaan.

Contoh kasus perusahaan di Indonesia yang mengalami kebangkrutan atas ketidakmampuan dalam memenuhi kewajibannya akibat penggunaan hutang sebagai sumber pendanaan perusahaan adalah PT. Metro Batavia yang dinyatakan pailit oleh Pengadilan Negeri Jakarta Pusat pada tahun 2013. Pailitnya PT. Metro Batavia tidak hanya meninggalkan hutang yang cukup besar kepada kreditur terutama perusahaan penyewaan pesawat, tetapi juga menimbulkan kerugian bagi para pemegang saham perusahaan. Demikian juga PT. Tunggal Yudi Sawmill Polywood yang dinyatakan pailit oleh Pengadilan Niaga Surabaya pada tahun 2016, karena tidak mampu membayar hutang usaha yang sudah mencapai Rp 140 Miliar.

Sejak krisis keuangan yang melanda Asia, pemerintah maupun investor semakin menyadari pentingnya sebuah tata kelola perusahaan yang baik. Salah satu contoh akibat lemahnya tata kelola perusahaan di Indonesia dapat kita lihat pada kasus PT. Bank Lippo,Tbk yang memanipulasi laporan keuangan pada tahun 2002, yang menimbulkan perbedaan informasi antara laporan keuangan yang disampaikan kepada publik dengan laporan keuangan yang disampaikan ke Bursa Efek Jakarta (bisnis.tempo.co.id). Kasus lainnya terjadi pada PT. Kereta Api Indonesia (PT. KAI). PT. KAI telah melakukan manipulasi data dalam laporan keuangan tahun 2005, PT. KAI dicatat 188 meraih keuntungan sebesar Rp6,9 Miliar. Padahal apabila diteliti dan dikaji lebih rinci perusahaan seharusnya menderita kerugian sebesar Rp63 Miliar. Kerugian yang dimanipulasi menjadi keuntungan, karena PT. KAI tidak memiliki tata kelola perusahaan yang baik (www.antaranews.com). Pada tahun 2009, kembali terjadinya kasus pada perusahaan PT. Katarina Utama,Tbk yang melakukan penyelewengan dana penawaran saham perdana. Manajemen perusahaan yang bergerak di bidang jasa penyewaan menara tersebut diduga melakukan penyelewengan atas dana IPO 2009 sebesar Rp33,6 miliar. Selain itu melakukan manipulasi laporan keuangan audit tahun 2009 dengan memasukkan sejumlah piutang fiktif guna memperbesar nilai aset perseroan (economy.okezone.com).

Kasus-kasus yang terjadi akibat lemahnya penerapan tata kelola perusahaan yang baik pada perusahaan di Indonesia. Lemahnya penerapan tata kelola perusahaan akan menurunkan nilai saham perusahaan, menurunnya citra perusahaan, serta juga mempengaruhi struktur modal dalam perusahaan. Berdasarkan uraian latar belakang di atas, maka penulis tertarik melakukan penelitian mengenai pengaruh tata kelola perusahaan dengan ukuran dewan, komposisi dewan, konsentrasi kepemilikan, kepemilikan manajerial, profitabilitas terhadap struktur modal dengan kualitas laporan keuangan sebagai mediasi.

\section{PERMASALAHAN DAN TUJUAN PENELITIAN}

Berdasarkan latar belakang yang telah diuraikan sebelumnya, maka dapat dirumuskan permasalahan penelitian sebagai berikut:

Apakah ukuran dewan, komposisi dewan, konsentrasi kepemilikan, dan kepemilikan manajerial berpengaruh terhadap struktur modal yang dimediasi oleh kualitas laporan keuangan pada perusahaan yang terdaftar Bursa Efek Indonesia?

Tujuan dari penelitian yang dilakukan adalah untuk mengetahui pengaruh ukuran dewan, komposisi dewan, konsentrasi kepemilikan, dan kepemilikan manajerial terhadap struktur modal yang dimediasi oleh kualitas laporan keuangan pada perusahaan yang terdaftar Bursa Efek Indonesia. 


\section{TINJAUAN PUSTAKA DAN PERUMUSAN HIPOTESIS}

Tujuan utama dari setiap perusahaan adalah memaksimalkan nilai perusahaan yang bergantung pada arus dana yang akan datang dan tingkat pendapatan sehingga perusahaan diharapkan dapat meningkatkan keuntungandan kesejahteraan bagi para pemegang saham. Untuk dapat mencapai tujuan tersebut perusahaan perlu memiliki sebuah struktur modal yang baik. Keberhasilan pemilihan dan penggunaan struktur modal merupakan salah satu elemen kunci dari strategi keuangan perusahaan (Velnampy \& Niresh, 2012).

Beberapa teori telah diajukan oleh pakar keuangan untuk melihat bagaimana hubungan tata kelola dengan struktur modal. Teori agency merupakan sebuah kontrak dimana satu atau lebih principal mempekerjakan orang lain (agen) dan memberikan agen tersebut kekuasaan membuat keputusan untuk menghasilkan jasa atas kepentingan principal (Jensen \& Meckling, 1976). Teori agency menimbulkan konflik kepentingan antara agen (manajer) perusahaan dan principal (pemegang saham). Manajer mempunyai insentif untuk membuat keputusan investasi yang mengurangi risiko dan meningkatkan kompensasi bagi para manajer. Masalah agency ini akan menimbulkan biaya agency yang berhubungan dengan biaya pengawasan dan biaya lainnya dari pemegang saham untuk memastikan para manajer bertindak untuk kepentingan dan meningkatkan kesejahteraan mereka. Berdasarkan teori agency, pembiayaan hutang dapat digunakan sebagai salah satu alat yang berguna dari tata kelola untuk mengurangi konflik kepentingan antara agen dan principal. Hutang dapat digunakan sebagai mekanisme tata kelola untuk mengurangi biaya agency dari arus kas bebas yang tersedia bagi para manajer untuk digunakan kembali bagi para investor bukan digunakan untuk kepentingan para manajer (Jensen, 1986).

Selanjutnya teori signalling menjelaskan bahwa biaya informasi asimetris timbul dimana hanya para manajer yang memiliki informasi pribadi mengenai peluang tingkat pengembalian atau keuntungan dari perusahaan, sedangkan para pemegang saham tidak memiliki informasi tersebut. Berdasarkan teori signalling, pilihan struktur modal bertindak sebagai sinyal bagi investor luar akan informasi yang dimiliki oleh pemegang saham. Setiap perubahan akan struktur modal akan merupakan sinyal bagi investor luar akan potensi kinerja perusahaan. Pengumuman pembiayaan hutang akan dianggap sebagai sinyal positif bagi para pemegang saham, yang berarti perusahaan mempunyai prospek keuangan yang bagus dan perusahaan mampu membayar dividen untuk para pemegang saham.

Teori pecking order berasumsi bahwa perusahaan lebih menyukai pembiayaan internal daripada eskternal, seperti arus kas dari operasi perusahaan (Myers, 1984; Myers, 2001). Jika perusahaan membutuhkan pembiayaan eksternal karena arus kas dari operasi tidak mencukupi untuk investasi modal, maka pertama-tama yang dipilih adalah pembiayaan dengan hutang yang paling aman (kurang berisiko). Myers (1984) menyatakan perusahaan lebih suka dengan pembiayaan hutang daripada pembiayaan dengan ekuitas karena biaya informasi yang lebih kecil. Hal ini akan meningkatkan rasio hutang terhadap ekuitas.

Beberapa peneliti terdahulu menyatakan bahwa mekanisme tata kelola perusahaan seperti ukuran dewan, komite audit, komposisi dewan komisaris, dualitas CEO, direksi eksternal, konsentrasi kepemilikan, kepemilikan manajerial dan kepemilikan institusi mempengaruhi keputusan struktur modal ( Wen et al, 2002; Hussainey \& Aljifri, 2012; Ahmadpour et al, 2012; Sheikh \& Wang, 2012; Marand et al, 2014; Jaradat, 2015). Hasil penelitian menyimpulkan bahwa tata kelola perusahaan memainkan peranan yang penting dalam penentuan struktur modal. Fungsi pengawasan dewan sangat penting dalam perspektif toeri keagenan, karena pembuatan keputusan berada pada manajemen puncak, maka dewan harus senantiasa mengawasi keputusan perusahaan secara keseluruhan (Jensen \& Meckling, 1986). Johnson et al (1996), Wen et al (2002) dan Graham et al (2011) tata kelola peusahaan mempengaruhi keputusan strategis yakni hutang.Pada penelitian ini dipilih ukuran dewan direksi, komposisi dewan komisaris, konsentrasi kepemilikan dan kepemilikan manajeria sebagai variabel bebas untuk menjelaskan struktur modal perusahaan.

\section{Hubungan Antar Variabel \\ Pengaruh Ukuran Dewan terhadap Struktur Modal}

Dewan direksi merupakan orang yang berperan dalam kepengurusan perseroan untuk mengelola perusahaan dan mengambil keputusan pendanaan. Ukuran dewan yang besar akan mendorong tingginya tingkat hutang guna meningkatkan asset perusahaan. 
Jaradat (2015) melakukan penelitian mengenai hubungan ukuran dewan terhadap struktur modal. Hasil penelitian menunjukkan bahwa adanya hubungan signifikan positif antara ukuran dewan terhadap struktur modal. Sebuah perusahaan yang sukses harus memiliki dewan yang efektif dalam melakukan perencanaan serta dalam mengambil keputusan yang berkaitan dengan pendanaan. Ganiyu \& Abiodun (2012) menambahkan bahwa ukuran dewan yang besar lebih rentan mengambil kesempatan untuk melakukan ekspansi dan eksploitasi yang berlebihan. Hasil penelitian Agyei \&Owusu (2014); Akbari \& Rahmani (2013) Kajananthan (2012), Ahmadpour et al (2012), Sheikh \& Wang (2012), Gill et al (2012), Hussainey \& Aljifri (2012); dan Abor (2007), menyatakan bahwa semakin besar jumlah dewan direksi dalam satu perusahaan, maka hutang perusahaan akan semakin besar. Hal ini bisa terjadi karena dengan semakin besar dewan direksi, mereka mempunyai jaringan yang besar, keahlian yang lebih besar sesuai bidangnya sehingga tata kelola perusahaan menjadi lebih baik, dan memberikan kepercayaan di mata investor untuk meminjamkan dananya bagi perusahaan.

Sementara itu, hasil penelitian yang dilakukan oleh Heng et al (2012), Vakilifard et al (2011) menunjukkan ukuran dewan berpengaruh signifikan negatif terhadap struktur modal. Perusahaan yang memiliki ukuran dewan direksi yang kecil serta lemahnya tata kelola perusahaan akan menggunakan jumlah utang yang semakin besar untuk mengurangi masalah agensi. Penelitian lain yang dilakukan oleh Khan \& Wasim (2016), Corsi \& Prencipe (2015), Marand (2015), Boochani \& Moradi (2012), Hussainey \& Aljifri (2012), Mousavi et al (2012), Rehman et al (2010) menunjukkan tidak ada hubungan yang signifikan antara ukuran dewan terhadap struktur modal dalam arti lain ukuran dewan direksi tidak mempengaruhi keputusan struktur modal perusahaan.

\section{Pengaruh Komposisi Dewan terhadap Struktur Modal}

Komposisi dewan merupakan anggota dewan yang berasal dari luar, direksi independen atau anggota dewan yang bukan merupakan anggota manajemen, pemegang saham mayoritas, pejabat atau dengan cara lain yang berhubungan langsung atau tidak langsung dengan pemegang saham mayoritas dari suatu perusahaan yang mengawasi pengelolaan perusahaan. Untuk perusahaan di Indonesia, komposisi dewan 190 adalah komposisi dewan komisaris independen dan komisaris perusahaan.

Jaradat (2015), Sheikh dan Wang (2012), Ganiyu dan Abiodun (2012), Kajananthan (2012), Boochani dan Moradi (2015), Agyei dan Owusu (2014) melakukan penelitian tentang hubungan antara komposisi dewan terhadap struktur modal. Hasil penelitian menunjukkan ada hubungan signifikan positif antara komposisi dewan dan struktur modal. Semakin tingginya dewan direktur non eksekutif ini akan meningkatkan rasio total hutang terhadap aset. Direktur non eskekutif menggunakan hutang jangka pendek dan hutang jangka panjang untuk pembiayaan di perusahaan.

Akbari dan Rahmani (2013), Heng et al (2012) menunjukkan ada hubungan signifikan negatif antara komposisi dewan dan struktur modal. Dewan non eskekutif ini akan memantau para manajer untuk kerja lebih efisien dan efektif sehingga manajer dipaksa untuk mencari cara mendapatkan struktur modal dengan tingkat risiko yang lebih rendah untuk mencapai hasil yang lebih unggul. Perusahaan dengan representasi yang lebih tinggi dari direktur non eksekutif diminta untuk menekan hutang yang rendah dengan nilai pasar yang tinggi dari ekuitas perusahaan.

Hal ini berbeda dengan penelitian yang dilakukan oleh Khan dan Wasim (2016), Zabri et al (2016), Ahmadpour et al (2012), Vakilifard et al (2011) yang tidak menemukan pengaruh yang signifikan dari komisaris independen terhadap pengambilan keputusan struktur modal.

\section{Pengaruh Konsentrasi kepemilikan terhadap Struktur Modal}

Konsentrasi kepemilikan menggambarkan bagaimana dan siapa saja yang memegang kendali atas keseluruhan atau sebagian besar kepemilikan perusahaan serta pemegang kendali aktivitas bisnis pada suatu perusahaan. Konsentrasi kepemilikan yang besar dalam suatu perusahan cenderung memiliki hutang yang lebih tinggi. Hal ini disebabkan oleh kepemilikan yang terkonsentrasi dapat menentukan keputusan manajemen sehingga dapat mendorong manajemen untuk meningkatkan tingkat hutang yang lebih tinggi karena biaya untuk melakukan pinjaman lebih rendah dibandingkan dengan menerbitkan saham baru untuk membiayai operasional perusahaan (Sheikh \&Wang, 2012).

Hasil penelitian Ahmadpour et al (2012) dan Sheikh dan Wang (2012) juga menunjukkan adanya hubungan positif antara konsentrasi 
kepemilikan terhadap struktur modal. Pemegang saham merupakan alat monitor yang efektif dan memiliki lebih banyak kemampuan untuk memaksa manajemen dalam mengambil tindakan untuk menggunakan tingkat hutang yang optimal daripada yang diinginkan secara pribadi oleh manajer dengan begitu akan dapat memaksimalkan pula kemakmuran pemegang saham. Tetapi bertolak belakang dengan penelitian yang dilakukan oleh Rehman et al (2010) dan Corsi dan Prencipe (2015) yang menunjukkan adanya hubungan negatif antara konsentrasi kepemilikan terhadap struktur modal. Hal ini berbeda dengan penelitian yang dilakukan oleh Mousavi et al. (2012) dan Rezaei et al. (2012) yang menunjukkan bahwa konsentrasi kepemilikan tidak berpengaruh secara signifikan terhadap struktur modal.

\section{Pengaruh Kepemilikan Manajerial terhadap Struktur Modal}

Kepemilikan manajerial merupakan para pemegang saham yang berasal dari manajemen yang secara aktif ikut dalam pengambilan keputusan. Perusahaan dengan kepemilikan manajerial besar cenderung mengejar tingkat hutang yang tinggi. Hal ini disebabkan oleh kepemilikan manajerial yang besar akan memberikan insentif yang lebih besar oleh perusahaan. Insentif keuangan yang dimiliki oleh manajer sangat terkait erat dengan kekayaan pemegang saham sehingga manajer akan menggunakan hutang yang tinggi untuk meningkatkan nilai perusahaan.

Rehman et al. (2010) menguji pengaruh kepemilikan manajerial terhadap struktur modal. Hasil penelitian menunjukkan bahwa terdapat pengaruh signifikan positif. Hal ini menunjukkan bahwa perusahaan dengan tingkat kepemilikan manajerial yang tinggi cenderung mengejar tingkat utang yang tinggi pula. Tingginya kepemilikan saham oleh pihak manajerial tersebut akan dapat meminimalkan masalah moral, informasi yang asimetris, memberikan insentif yang besar dan meningkatkan kemampuan dalam memantau tindakan para manajer, sehingga perusahaan akan cenderung mengadopsi hutang yang tinggi. Tetapi bertolak belakang dengan penelitian yang dilakukan oleh Corsi dan Prencipe (2015), Akbari dan Rahmani (2013), dan Sheikh dan Wang (2012) menunjukkan bahwa kepemilikan manajerial berpengaruh signifikan negatif terhadap struktur modal.

\section{Pengaruh Profitabilitas (Variabel Kontrol) terhadap Struktur Modal}

Profitabilitas merupakan suatu ukuran dalam persentase yang digunakan untuk menilai sejauh mana perusahaan mampu menghasilkan laba pada tingkat yang dapat diterima. Perusahaan dengan tingkat profitabilitas yang tinggi cenderung menggunakan proporsi utang yang kecil. Hal ini disebabkan oleh profitabilitas yang tinggi akan menyediakan sejumlah dana internal yang besar untuk membiayai operasional perusahaan dan memiliki kesempatan untuk menginvestasi yang berasal dari laba ditahan (Sheikh dan Wang, 2012).

Khan dan Wasim (2016), Zabri et al (2016), Jaradat (2015), Boochani dan Moradi (2015), Mirza (2015), Corsi dan Prencipe (2015), Ganiyu dan Abiodun (2012), Al-Najjar dan Peter (2008), Akbari dan Rahmani (2013), Sheikh dan Wang (2012), Hussainey dan Aljifri (2012) melakukan penelitian tentang hubungan profitabilitas terhadap struktur modal. Hasil penelitian menunjukkan bahwa adanya hubungan signifikan negatif antara komposisi dewan dan struktur modal. Teori Pecking Order mengatakan bahwa perusahaan menggunakan dana internal sebagai prioritas utama untuk membiayai beban, kedua yaitu hutang, dan pilihan terakhir yaitu ekuitas perusahaan untuk membiayai investasi modal perusahaan. Perusahaan dengan tingkat profitabilitas yang tinggi umumnya menggunakan kewajiban dengan jumlah yang relatif sedikit. Apabila perusahaan menggunakan kewajiban dalam jumlah yang besar tidak akan berpengaruh terhadap struktur modal, karena kemampuan perusahaan dalam membayar bunga tetap juga tinggi akibat laba yang tinggi pula. Tingkat pengembalian yang tinggi memungkinkan untuk membiayai sebagian besar kebutuhan pendanaan dengan dana yang dihasilkan secara internal.

\section{Pengaruh Corporate Governance terhadap Struktur Modal dengan Kualitas Laporan Keuangan sebagai Variabel Mediasi}

Penelitian terdahulu meneliti hubungan antara tata kelola dengan struktur modal. Tetapi hanya sedikit yang menunjukkan bagaimana proses ini terjadi. Beberapa peneliti berpendapat bahwa jika praktek tata kelola dijalankan dengan baik, maka struktur modal perusahaan akan tinggi (Wen et al., 2002; Claessens \& Fan, 2002). Arping dan Sautner menambahkan bahwa peningkatan tata kelola akan mengurangi hutang perusahaan. Namun yang lainnya berargumen bahwa jika 
nilai tata kelola perusahaan rendah maka hutang perusahan akan tinggi (Jiraporn et al., 2012).

Krisis di Indonesia tahun 1997 menujukkan bahwa hutang yang berlebihan membuat kebangkrutan pada perusahaan. Bukti menyarankan bahwa jika dewan tidak memitigasi risiko dari hutang yang berlebihan, maka perusahaan kemungkinan akan menderita kebangkrutan (Murphy \& Brown, 2009). Perusahaan yang sangat bergantung pada pembiayaan hutang harus membayar biaya pinjaman yang tetap dan bank cenderung mengenakan bunga pinjaman yang lebih besar karena kemungkinan bangkrut menjadi lebih tinggi. Hal ini membantu pemahaman bahwa kinerja perusahaan menurun dari dewan yang tidak mampu mendapatkan struktur modal yang berisiko (Johnson, Daily \& Ellstrand, 1996). Dengan demikian jika dewan direksi memainkan perannya dengan efektif, maka dapat mempengaruhi manajemen untuk memperoleh struktur modal yang kurang berisiko dan hutang yang berlebihan (Kassim et al., 2013).

Fungsi pengawasan dewan sangat penting dalam perspektif toeri keagenan, karena pembuatan keputusan berada pada manajemen puncak, maka dewan harus senantiasa mengawasi keputusan perusahaan secara keseluruhan (Jensen \& Meckling, 1986). Johnson et al (1996), Wen et al (2002) dan Graham et al (2011) tata kelola peusahaan mempengaruhi keputusan strategis yakni hutang. Investigasi lebih lanjut antara kualitas pelaporan keuangan dengan struktur modal, khususnya pembiayaan dari hutang menunjukkan bahwa para kreditur mensyaratkan bunga yang lebih tinggi untuk perusahaan yang lebih berisiko. Menurut trade off theory, risiko yang lebih tinggi maka hutang harus lebih kecil, karena arus kas di masa yang akan datang mungkin tidak cukup tinggi untuk membayar kembali hutang. Potensi biaya kebangkrutan meningkatkan biaya modal dan mengurangi kemampuan perusahaan untuk mendapatkan pembiayaan dari eksternal (hutang). Dengan demikian perusahaan yang mempunyai kualitas informasi yang lebih tinggi, secara signifikan akan menurunkan masalah akses terhadap pembiayaan eksternal dibandingkan dengan peusahaan lain. Studi empiris membuktikan bahwa kualitas pelaporan keuangan yang tercermin dalam arus kas operasi yang lebih tinggi berhubungan dengan perolehan pembiayaan hutang dengan biaya yang lebih kecil, dan meningkatkan pembiayaan hutang perusahaan.
Kualitas laporan keuangan berhubungan dengan kinerja keseluruhan perusahaan yang tergambarkan dalam laba perusahaan. Pelaporan keuangan dikatakan tinggi (berkualitas) jika laba tahun berjalan dapat menjadi indikator yang baik untuk laba perusahaan dimasa yang akan datang. Fokus pengukuran kualitas pelaporan keuangan perusahaan tersebut berkaitan dengan sifat-sifat pelaporan keuangan. Kualitas laporan keuangan juga berkaitan dengan kinerja pasar modal yang diwujudkan dalam bentuk imbalan, sehingga hubungan yang semakin kuat antara laba perusahaan dengan imbalan menunjukkan informasi pelaporan keuangan yang tinggi. Kualitas laporan keuangan bisa dinilai dari arus kas operasi perusahaan tersebut. Sariman et al (2013) menyatakan bahwa tata kelolo perusahaan memiliki pengaruh signifikan terhadap struktur modal yang dimediasikan oleh kualitas laporan keuangan.

\section{Perumusan Hipotesis}

Hipotesis untuk penelitian ini adalah:

$\mathrm{H}_{1}$ : Kualitas laporan keuangan memediasi hubungan ukuran dewan dan struktur modal.

$\mathrm{H}_{2}$ : Kualitas laporan keuangan memediasi hubungan komposisi dewan dan struktur modal.

$\mathrm{H}_{3}$ : Kualitas laporan keuangan memediasi hubungan konsentrasi kepemilikan dan struktur modal.

$\mathrm{H}_{4}$ : Kualitas laporan keuangan memediasi hubungan kepemilikan manajerial dan struktur modal.

\section{METODE PENELITIAN \\ Rancangan Penelitian}

Jenis penelitian yang digunakan dalam penelitian ini bersifat kuantitatif yaitu mengembangkan dan mengevaluasi konsep-konsep teoritis dengan menguji apakah variabel dependen dipengaruhi oleh variabel independen (Indriatoro \& Supomo, 2002). Pedekatan yang digunakan yaitu penelitian kausal komparatif (causal comparative research). Dikatakan penelitian kausal komparatif karena untuk meneliti apakah ada hubungan sebab akibat antara variabel ukuran dewan, komposisi dewan, konsentrasi kepemilikan kepemilikan manajerial, profitabilitas dan kualitas laporan keuangan sebagai mediasi terhadap struktur modal pada perusahaan yang terdaftar di Bursa Efek Indonesia. 


\section{Objek Penelitian}

Populasi penelitian yang diteliti adalah laporan keuangan perusahaan yang terdaftar di dalam Bursa Efek Indonesia selama periode 2011-2015 sebanyak 525 perusahaan dengan 217 perusahaan yang dijadikan sampel. Metode pemilihan sampel yang digunakan adalah purposive sampling, yaitu pemilihan sampel secara tidak acak berdasarkan pertimbangan dan kriteria tertentu yang disesuaikan dengan tujuan penelitian yaitu: perusahaan yang menerbitkan laporan keuangan tahunan selama periode 20112015, perusahaan yang terdaftar di Bursa Efek Indonesia, Perusahaan yang memiliki laporan keuangan yang lengkap, perusahaan yang diluar sektor keuangan dan perusahaan yang menerbitkan laporan keuangan per 31 Desember.

\section{Definisi Operasional Variabel}

Penelitian ini menggunakan variabel independen, mediasi, dependen dan kontrol. Variabel dependen yang digunakan adalah struktur modal. Variabel independen yaitu ukuran dewan, komposisi dewan, konsentrasi kepemilikan dan kepemilikan manajerial. Variabel mediasi yaitu kualitas laporan keuangan. dan provitabilitas sebagai variabel kontrol.

\section{Variabel Dependen}

Variabel dependen merupakan suatu variabel yang dipengaruhi atau yang menjadi akibat karena adanya variabel bebas/variabel independen. Dalam penelitian ini, penulis memilih untuk menggunakan struktur modal sebagai variabel dependen. Struktur modal pertama kali dikemukakan oleh Modigliani dan Miller (1958). Struktur modal yang optimal didefinisikan sebagai struktur modal yang meminimalkan tingkat kebangkrutan serta memaksimalkan kekayaan pemegang saham. Keberhasilan dalam pengambilan keputusan struktur modal merupakan suatu hal yang penting karena akan mempengaruhi secara langsung profitabilitas suatu perusahaan. Keberhasilan pemilihan dan penggunaan modal merupakan salah satu elemen kunci dari strategi keuangan perusahaan (Velnampy \& Niresh, 2012). Dalam penelitian ini, struktur modal diukur dengan rasio utang (Leverage), yaitu Total hutang/total aset (Gitman, 2006)

\section{Variabel Independen}

Menurut Sugiyono (2009) variabel independen merupakan variabel yang mempengaruhi suatu yang menjadi sebab perubahannya atau timbulnya variabel dependen. Variabel independen dalam penelitian ini adalah ukuran dewan, komposisi dewan, konsentrasi kepemilikan dan kepemilikan manajerial.

Ukuran Dewan

Ukuran dewan merupakan jumlah total anggota yang terdapat dalam dewan direksi (Ghabayen, 2011). Ukuran dewan dihitung berdasarkan jumlah anggota direksi dalam sebuah perusahaan (Ganiyu \& Abiodun, 2012).

Komposisi Dewan Independen

Komposisi dewan independen merupakan anggota dewan yang berasal dari luar, direksi independen atau anggota dewan yang bukan merupakan anggota manajemen, pemegang saham mayoritas, pejabat atau dengan cara lain yang berhubungan langsung atau tidak langsung dengan pemegang saham mayoritas dari suatu perusahaan yang mengawasi pengelolaan perusahaan. Komposisi dewan dapat diukur dengan menggunakan rumus sebagai berikut (Ganiyu \& Abiodun, 2012)

Komposisi Dewan $=$ jumlah komisaris independen/ jumlah komisaris

Konsentrasi Kepemilikan

Konsentrasi kepemilikan menggambarkan tentang bagaimana dan siapa saja yang memegang kendali atas keseluruhan atau sebagian besar atas kepemilikan perusahaan serta keseluruhan atau sebagian besar pemegang kendali atas aktivitas bisnis perusahaan tersebut. Ukuran konsentrasi kepemilikan suatu perusahaan diukur dengan menggunakan persentasi kepemilikan terbesar pada perusahaan ( Rehman et al, 2010)

$$
\text { Konsentrasi Kepemilikan }=\frac{\text { Jumlah Kepemilikan Saham Terbesar }}{\text { Total Saham }} \times 100 \%
$$

Kepemilikan Manajerial

Kepemilikan manajerial merupakan jumlah pemegang saham yang juga sebagai pemilik atau dari pihak manajemen yang secara aktif ikut dalam pengambilan keputusan. Pengukuran kepemilikan manajerial diukur dengan persentase atas kepemilikan manajemen terhadap total kepemilikan (Rehman et al, 2010)

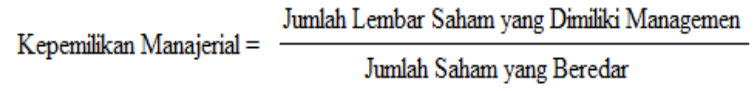




\section{Variabel Mediasi}

Variabel intervening atau variabel mediasi merupakan variabel yang secara teoritis mempengaruhi hubungan antara variabel independen dan dependen menjadi hubungan tidak langsung dan tidak dapat diamati dan diukur. Variabel ini merupakan variabel penyela antara variabel independen dengan variabel dependen, sehingga variabel independen tidak langsung mempengaruhi munculnya variabel dependen. Variabel mediasi dalam penelitian ini yaitu kualitas laporan keuangan. Kualitas laporan keuangan berhubungan dengan kinerja keseluruhan perusahaan yang tergambarkan dalam laba perusahaan. Pelaporan keuangan dikatakan tinggi (berkualitas) jika laba tahun berjalan dapat menjadi indikator yang baik untuk laba perusahaan dimasa yang akan datang. Fokus pengukuran kualitas pelaporan keuangan perusahaan tersebut berkaitan dengan sifat-sifat pelaporan keuangan. Kualitas laporan keuangan juga berkaitan dengan kinerja pasar modal yang diwujudkan dalam bentuk imbalan, sehingga hubungan yang semakin kuat antara laba perusahaan dengan imbalan menunjukkan informasi pelaporan keuangan yang tinggi. Kualitas laporan keuangan di proksi dengan arus kas operasi (CFO) (Sariman et al, 2013) dan diukur dengan rumus berikut ini (Gitman, 2006).

$$
C F O=\text { NOPAT }+ \text { Depreciation }
$$

\section{Variabel Kontrol}

Konsisten dengan penelitian terdahulu antara lain: Sariman et al (2013); Boochani \& Moradi (2015), dalam penelitian ini juga dimasukkan profitabilitas sebagai variabel kontrol.

Profitabilitas merupakan suatu pengukuran yang menunjukkan kemampuan perusahaan untuk menghasilkan keuntungan dan mengukur tingkat efisiensi operasional dan efisiensi dalam menggunakan aset yang dimilikinya. Skala pengukuran variabel profitabilitas adalah skala rasio (Jaradat, 2015)

$$
\text { Profitabilitas }=\frac{\text { Laba Bersih Setelah Pajak }}{\text { Total Aktiva }}
$$

\section{Teknik Pengumpulan Data}

Dalam penelitian ini, penulis akan menggunakan metode dokumentasi dalam mengumpulkan data yang akan diteliti. Metode dokumentasi merupakan metode dengan cara mengumpulkan, mencatat seta mengkajikan data sekunder yang dipublikasikan, yaitu laporan keuangan tahunan 194 perusahaan-perusahaan yang terdaftar di Bursa Efek Indonesia pada periode 2011-2015.

\section{Metode Analisis Data}

Metode analisis data yang digunakan dalam penelitian ini adalah multiple linear regression analysis, yaitu teknik statistika untuk membuat model dan menyelidiki pengaruh antara beberapa variabel independen terhadap variabel dependen yang dimediasi oleh variabel mediasi. Data yang berhasil dikumpulkan akan diproses dengan menggunakan aplikasi perangkat lunak SPSS (Statistical Package for the Social Science) untuk memberikan gambaran mengenai hubungan yang jelas antar variabel independen terhadap variabel dependen.

\section{Uji t}

Uji t digunakan untuk menguji besarnya pengaruh variabel independen terhadap variabel dependen. Suatu variabel independen dikatakan memiliki pengaruh signifikan terhadap variabel dependen bila nilai signifikansi lebih kecil dari 0,05 atau nilai $t$ hitung lebih besar dari nilai $t$ tabel dan dikatakan tidak memiliki pengaruh signifikan bila lebih besar dari 0,05. Angka unstandardized coefficient $B$ akan menunjukkan besar dan arah pengaruh setiap variabel independen maupun variabel mediasi terhadap variabel dependen.

\section{Uji Koefisien Determinasi $\left(\mathbf{R}^{2}\right)$}

Uji koefisien determinasi digunakan untuk mengetahui seberapa besar pengaruh variabel independen terhadap variabel dependen. Nilai adjusted $\mathrm{R}^{2}$ yang rendah diartikan memiliki pengaruh yang kecil, yaitu dibawah 0,5 , sedangkan di atas 0,5 memiki pengaruh yang besar. Uji koefisien determinasi menjelaskan hubungan antara variabel dan adanya faktor lain yang tidak terdapat dalam model penelitian yang mempengaruhi hubungan tersebut (Santoso, 2014).

\section{Pengujian Variabel Mediasi}

Variabel mediasi atau intervening merupakan variabel antara yang berfungsi memediasi hubungan antara variabel independen dengan variabel dependen. Analisis regresi variabel mediasi dengan dapat dilakukan dengan metode causal step yang dikembangkan oleh Baron dan Kenny (1986). Untuk memahami pengujian mediasi menggunakan metode ini maka digunakan persamaan sebagai berikut: 
Persamaan 1

Persamaan 2

Debt Ratio

Mediasi

$=\alpha+\beta_{1} X_{1}+\beta_{2} X_{2}+\beta_{3} X_{3}+\beta_{4} X_{4}+\beta_{3} X_{5}+\mathrm{e}$

Persamaan 3

dimana:

$Y=$ Struktur Modal (Rasio utang); $M=$ Medias; $\alpha=$ Beta Konstanta; $\beta=$ Koefisien Regresi

$X_{1}=$ Ukuran Dewan; $X_{2}=$ Komposisi Dewan; $X_{3}=$ Konsentrasi Kepemilikan;

$X_{4}=$ Kepemilikan Manajerial; $X_{5}=$ Profitabilitas; $M=$ Kualitas Laporan Keuangan; e $=$ Error

Persamaan $1=$ penganh variabel independen terhadap variabel dependen

Persamaan $2=$ penganuh variabel independen terhadap variabel mediasi.

Persamaan $3=$ pengaruh variabel independen dan variabel mediasi terhadap variabel dependen

Variabel mediasi dinyatakan sebagai variabel mediasi sempurna jika setelah memasukkan variabel mediasi, pengaruh variabel independen terhadap variabel dependen menurun menjadi nol $(\mathrm{c}=0)$ atau pengaruh variabel independen terhadap variabel dependen yang tadinya signifikan (sebelum memasukkan variabel mediasi) menjadi tidak signifikan setelah memasukkan variabel mediasi kedalam model persamaan regresi. Variabel mediasi dinyatakan sebagai variabel mediasi parsial jika setelah memasukkan variabel mediasi, pengaruh antara variabel independen dan variabel dependen yang tadinya signifikan (sebelum memasuki variabel mediasi) menjadi tetap signifikan setelah memasukkan variabel mediasi kedalam model persamaan regresi, tetapi mengalami penurunan koefisien regresi.

\section{ANALISIS DAN PEMBAHASAN Statistik Deskriptif}

Hasil Uji statistik deskriptif dapat dilihat pada Tabel 1 yang menggambarkan nilai minimum, maksimum, rata-rata dan simpangan baku (Standard Deviation) setiap variabel.

Tabel 1. Statistik Deskriptif

\begin{tabular}{lccccc}
\hline \multicolumn{7}{c}{ Descriptive Statistics } \\
& N & Minimum & Maximum & Mean & Std. Deviation \\
\hline Capital Structure & 874 & 0,0327 & 0,7987 & 0,4478 & 0,1511 \\
Board Size & 874 & 40,000 & 210,000 & 98,000 & 33,350 \\
Board Composition & 874 & 0,0000 & 0,7500 & 0,3782 & 0,1208 \\
Ownership Concentration & 874 & 0,0000 & 10,000 & 0,6935 & 0,1859 \\
Managerial Ownership & 874 & 0,0000 & 0,8750 & 0,0261 & 0,0983 \\
Profitability & 874 & $-0,1182$ & 0,4112 & 0,0753 & 0,0713 \\
Financial Report Quality & 874 & 85,403 & 136,217 & 113,849 & 0,8008 \\
Valid N (istwise) & 874 & & & & \\
\hline
\end{tabular}

Sumber: Data sekunder diolah (2016)

Tabel 2 menunjukkan bahwa variabel komposisi dewan, konsentrasi kepemilikan, kepemilikan manajerial dan profitabilitas memiliki nilai signifikansi kurang dari 0,05, sehingga keempat variabel tersebut memiliki pengaruh yang signifikan terhadap struktur modal yang diukur dengan Debt Ratio. Sedangkan variabel ukuran dewan memiliki nilai signifikansi yang lebih dari 0,05 sehingga tidak memiliki pengaruh yang signifikan terhadap Debt Ratio.

\section{Hasil Uji t (Variabel independen terhadap variabel mediasi)}

Hasil uji t digunakan untuk melihat pengaruh antara masing-masing variabel independen terhadap variabel mediasi yaitu kualitas laporan keuangan. Hasil uji t pada model regresi ini dapat dilihat dalam Tabel 3, yang menunjukkan bahwa variabel ukuran dewan, komposisi dewan, konsentrasi kepemilikan, kepemilikan managerial dan profitabilitas memiliki nilai signifikansi kurang dari sama dengan 0,05 atau t hitung lebih besar dari $\mathrm{t}$ tabel $(1,96$ atau -1,96) sehingga kelima variabel tersebut memiliki pengaruh yang signifikan terhadap kualitas laporan keuangan yang diukur dengan Cash Flow Operation.

Tabel 3.Hasil Uji t Variabel Independen ke Variabel Mediasi

\begin{tabular}{|c|c|c|c|c|c|}
\hline & \multicolumn{2}{|c|}{ Instandardized Coefficients } & \multirow{2}{*}{$t$} & \multirow{2}{*}{ Sig. } & \multirow{2}{*}{ Keterangan } \\
\hline & B & Std. Error & & & \\
\hline (Constant) & 8,537 & 0,160 & 53,369 & 0,000 & \\
\hline Board Size & 3,266 & 0,125 & 26,207 & 0,000 & Sigrifikan Positif \\
\hline Board Composition & 0,300 & 0.152 & 1,966 & 0,050 & Signifikan Positif \\
\hline Ownership Concentration & $-0,929$ & 0,109 & 8,488 & 0,000 & Siginifikan Negatif \\
\hline Managerial Onnership & $-1,304$ & 0,205 & $-6,347$ & & Sigriflian Negatif \\
\hline Profitabilily & 3,404 & 0,254 & 13,409 & 0,000 & Sigrifikan Positif \\
\hline
\end{tabular}

Sumber: Data sekunder diolah (2016)

Hasil uji t (variabel independen, variabel mediasi terhadap variabel dependen)

Hasil uji t dan nilai beta digunakan untuk melihat pengaruh antara masing-masing variabel independen terhadap variabel dependen yang dimediasi oleh kualitas laporan keuangan. Hasil uji t pada model regresi ini dapat dilihat dalam Tabel 4, menunjukkan bahwa variabel ukuran dewan, komposisi dewan, konsentrasi kepemilikan, kepemilikan managerial dan profitabilitas memiliki nilai t hitung lebih besar dari t tabel $(1,96$ atau -1,96) dan nilai signifikansi kurang dari 0,05, sehingga kelima variabel tersebut memiliki pengaruh yang signifikan terhadap struktur modal yang diukur dengan rasio Hutang. Sedangkan variabel konsentrasi kepemilikan memiliki nilai signifikansi yang lebih dari 0,05 sehingga dapat disimpulkan tidak memiliki pengaruh yang signifikan terhadap rasio hutang. 
Tabel 4. Hasil Uji t variabel Independen ke Variabel Dependen dengan Pengaruh Variabel Mediasi

\begin{tabular}{|c|c|c|c|c|}
\hline & \multicolumn{2}{|c|}{ Unstandardized } & \multirow{2}{*}{$\mathrm{T}$} & \multirow{2}{*}{ Keterangan } \\
\hline & B & Std. Error & & \\
\hline (Constant) & 0,112 & 0,077 & 1,459 & 0,145 \\
\hline Board Size & $-0,165$ & 0,039 & $-4,267$ & 0,000 Signifikan Negatif \\
\hline Board Composition & 0,194 & 0,035 & 5,483 & 0,000 Signifikan Positif \\
\hline Ownership Concentration & $-0,030$ & 0,026 & $-1,132$ & 0,258 Tidak Signifikan \\
\hline Managerial Ownership & $-0,242$ & 0,049 & $-4,969$ & 0,000 Signifikan Negatif \\
\hline Profitability & $-1,220$ & 0,065 & $-18,875$ & 0,000 Signifikan Negatif \\
\hline Financial Report Quality & 0,047 & 0,008 & 6,040 & 0,000 Signifikan Positif \\
\hline Var. Dependent : Debt Ratio & & & & \\
\hline
\end{tabular}

Sumber: Data Sekunder diolah (2016)

Ukuran dewan dan struktur modal.

Dalam Tabel 6 dapat dilihat bahwa variabel ukuran dewan memiliki nilai signifikansi sebesar 0,741 yang lebih besar dari 0,05 dan nilai beta sebesar -0,010. Hasil tersebut menandakan bahwa ukuran dewan memiliki pengaruh negatif terhadap struktur modal tetapi tidak signifikan. Dewan direksi umumnya mengadopsi kebijakan utang yang rendah. Akan tetapi, ukuran dewan direksi tidak memiliki pengaruh yang signifikan bagi perusahaan dalam mengatur pendanaan demi terciptanya keputusan struktur modal yang baik. Hasil penelitian ini konsisten dengan penelitian terdahulu oleh Corsi \& Prencipe (2015), Marand (2015), Boochani \& Moradi (2012), Hussainey \& Aljifri (2012), Mousavi et al (2012), Rehman et al (2010). Tetapi bertolak belakang dengan penelitian oleh Jaradat (2015), Agyei \& Owusu (2014), Akbari \& Rahmani (2013), Ganiyu \& Abiodun (2012), Kajananthan (2012), Ahmadpour et al (2012), Sheikh \& Wang (2012), Gill et al (2012), Heng et al (2012), Vakilifard et al (2011).
Tabel 5. Hasil Uji t Gabungan

\begin{tabular}{|c|c|c|c|c|}
\hline & \multicolumn{2}{|c|}{$\begin{array}{c}\text { Unstandardized } \\
\text { Coefficients }\end{array}$} & \multirow[t]{2}{*}{$\mathrm{T}$} & \multirow[t]{2}{*}{ Keterangan } \\
\hline & B & Std. Error & & \\
\hline (Constant) & 0,517 & 0,038 & 13,683 & 0,000 \\
\hline Board Size & $-0,010$ & 0,029 & $-0,331$ & 0,741 Tidak Signifikan \\
\hline Board Composition & 0,208 & 0,036 & 5,781 & 0,000 Signifikan Positif \\
\hline Ownership Concentration & $-0,074$ & 0,026 & $-2,860$ & 0,004 Signifikan Negatif \\
\hline Managerial Ownership & $-0,304$ & 0,049 & $-6,258$ & 0,000 Signifikan Negatif \\
\hline Profitability & $-1,058$ & 0,060 & $-17,632$ & 0,000 Signifikan Negatif \\
\hline \multicolumn{5}{|c|}{ a. Dependent Variable: Capital Structure } \\
\hline (Constant) & 8,537 & 0,160 & 53,369 & 0,000 \\
\hline Board Size & 3,266 & 0,125 & 26,207 & 0,000 Signifikan Positif \\
\hline Board Composition & 0,300 & 0,152 & 1,966 & 0,050 Signifikan Positif \\
\hline Ownership Concentration & $-0,929$ & 0,109 & $-8,488$ & 0,000 Signifikan Negatif \\
\hline Managerial Ownership & $-1,304$ & 0,205 & $-6,347$ & 0,000 Signifikan Negatif \\
\hline Profitability & 3,404 & 0,254 & 13,409 & 0,000 Signifikan Positif \\
\hline \multicolumn{5}{|c|}{ a. Dependent Variable: Financial Report Quality } \\
\hline (Constant) & 0,112 & 0,077 & 1,459 & 0,145 \\
\hline Board Size & $-0,165$ & 0,039 & $-4,267$ & 0,000 Signifikan Negatif \\
\hline Board Composition & 0,194 & 0,035 & 5,483 & 0,000 Signifikan Positif \\
\hline Ownership Concentration & $-0,030$ & 0,026 & $-1,132$ & 0,258 Tidak Signifikan \\
\hline Managerial Ownership & $-0,242$ & 0,049 & $-4,969$ & 0,000 Signifikan Negatif \\
\hline Profitability & $-1,220$ & 0,065 & $-18,875$ & 0,000 Signifikan Negatif \\
\hline Financial Quality Report & 0,047 & 0,008 & 6,040 & 0,000 Signifikan Positif \\
\hline
\end{tabular}

Sumber: Data sekunder diolah (2016)

Tabel 6. Perbedaan Uji t sebelum mediasi \& sesudah mediasi

\begin{tabular}{lccccc}
\hline & Beta & $\begin{array}{c}\text { Beta } \\
\text { Mediasi }\end{array}$ & Sig & $\begin{array}{c}\text { Sig } \\
\text { Mediasi }\end{array}$ & Keterangan \\
\hline (Constant) & 0,517 & 0,112 & 0,000 & 0,145 \\
Board Size & $-0,010$ & $-0,165$ & 0,741 & 0,000 Tidak terjadi mediasi \\
Board Composition & 0,208 & 0,194 & 0,000 & 0,000 Mediasi parsial \\
Ownership Concentration & $-0,074$ & $-0,030$ & 0,004 & 0,258 Mediasi sempurna \\
Managerial Ownership & $-0,304$ & $-0,242$ & 0,000 & 0,000 Mediasi parsial \\
Profitability & $-1,058$ & $-1,220$ & 0,000 & 0,000 Tidak terjadi mediasi \\
\hline
\end{tabular}

Pada Tabel 6 menunjukkan gabungan hasil uji persamaan satu-tiga

1. = Hasil Uji t variabel Independen terhadap variabel dependen.

2. $\quad=$ Hasil Uji t variabel Independen terhadap variabel mediasi.

3. = Hasil Uji t variabel Independen terhadap variabel dependen dengan pengaruh variabel mediasi.

\section{Komposisi dewan independen dan struktur modal.}

Variabel komposisi dewan memiliki nilai signifikansi sebesar 0,000 dan nilai beta sebesar 0,208 . Hal ini menunjukkan bahwa komposisi dewan memiliki pengaruh positif yang signifikan terhadap struktur modal. Nilai beta sebesar 0,208 menunjukkan bahwa setiap peningkatan variabel komposisi dewan independen sebesar satu akan meningkatkan struktur modal sebesar 0,208. Dewan komisaris independen memungkinkan 
komisaris luar untuk mengontrol tindakan manajemen dan mengambil menjalankan tata kelola perusahaan yang baik. Semakin banyak jumlah anggota dewan komisaris independen maka semakin tinggi pula kecenderungan untuk mengejar kebijakan hutang. Jumlah dewan komisaris independen yang tinggi lebih aktif memonitor manajemen dan menambah sumber pendanaan perusahaan dari pihak luar yang dapat meningkatkan rasio utang. Hasil penelitian ini konsisten dengan penelitian yang dilakukan oleh Jaradat (2015), Sheikh \& Wang (2012), Ganiyu \& Abiodun (2012), Kajananthan (2012), Boochani \& Moradi (2015), Agyei \& Owusu (2014).

\section{Konsentrasi kepemilikan dan struktur modal}

Nilai signifikansi untuk konsentrasi kepemilikan sebesar 0,004 dengan nilai beta -0,074. Hasil ini menunjukkan bahwa konsentrasi kepemilikan memiliki pengaruh negatif yang signifikan terhadap struktur modal. Setiap peningkatan variabel konsentrasi kepemilikan sebesar 1 akan menurunkan nilai variabel struktur modal sebesar 0,074 . Hasil penelitian ini menunjukkan bahwa kepemilikan yang terkonsentrasi akan mengurangi utang perusahaan. Hal ini konsisten dengan penelitian Corsi dan Prencipe (2015) yang mengatakan blockholders yang besar cenderung mengurangi penggunaan utang untuk menghindari semua pilihan pendanaan perusahaan dimasa yang akan datang.

Kepemilikan manajerial dan struktur modal Variabel kepemilikan manajerial memiliki nilai beta sebesar -0,304 dengan tingkat signifikansi sebesar 0,000. Hasil tersebut menandakan bahwa kepemilikan manajerial memiliki pengaruh negatif yang signifikan terhadap struktur modal. Semakin besar kepemilikan manajerial akan menyelaraskan kepentingan manajer dan kepentingan pemegang saham luar serta mengurangi proporsi utang untuk mengurangi masalah keagenan (Sheikh \& Wang, 2012). Apabila proporsi kepemilikan saham oleh pihak manajerial meningkat, maka pemegang saham eksternal lainnya akan menyerahkan pengawasnya kepada pihak manajerial. Pihak manajerial akan cenderung untuk menghindari penggunaan utang dan menjadi risk-averse. Hal ini dilakukan untuk menghindari terjadinya risiko kebangkrutan. Hasil penelitian ini didukung dengan penelitian yang dilakukan oleh Corsi \& Prencipe (2015), Akbari \& Rahmani (2013), Sheikh \& Wang (2012).

\section{Profitabilitas dan struktur modal}

Variabel profitabilitas memiliki nilai sig 0,000 dan beta -1,058. Hasil tersebut menandakan bahwa variabel profitabilitas berpengaruh negatif terhadap struktur modal. Perusahaan yang memiliki tingkat profitabilitas yang tinggi tidak membutuhkan pendanaan yang berasal dari pinjaman utang, karena mereka dapat menggunakan dana yang dihasilkan oleh internal perusahaan itu sendiri. Hasil dari pengujian ini konsisten dengan penelitian yang dilakukan oleh Jaradat (2015), Ganiyu \& Abiodun (2012), Boochani \& Moradi (2015), Akbari \& Rahmani (2013), Sheikh dan Wang (2012).

\section{$\mathrm{H}_{1}$ kualitas laporan keuangan memediasi hubungan ukuran dewan dan struktur modal}

Variabel ukuran dewan setelah dimediasi oleh kualitas laporan keuangan memiliki nilai signifikansi 0,000 dan beta -0,165 (nilai beta mengalami peningkatan) menandakan bahwa variabel tersebut memiliki pengaruh negatif yang signifikan terhadap struktur modal. Namun kualitas laporan keuangan sebagai variabel mediasi, tidak memediasi hubungan variabel ukuran dewan terhadap struktur modal karena sebelum memasukkan variabel mediasi, ukuran dewan memiliki nilai signifikansi sebesar 0,741 dan nilai beta -0,01dan sesudah dimediasi nilai beta pengalami peningkatan. Dengan demikian hipotesis ini ditolak.

\section{$\mathrm{H}_{2}$ kualitas laporan keuangan memediasi hubungan komposisi dewan independen dan struktur modal}

Variabel komposisi dewan independen setelah dimediasi oleh kualitas laporan keuangan memiliki nilai signifikansi 0,000 dan beta 0,194 (nilai beta mengalami penurunan) menandakan bahwa variabel tersebut memiliki pengaruh positif yang signifikan terhadap struktur modal. Hal ini menunjukkan bahwa kualitas laporan keuangan sebagai variabel mediasi, memediasi parsial hubungan variabel komposisi dewan independen terhadap struktur modal, dari yang sebelum memasukkan variabel mediasi, komposisi dewan independen memiliki nilai signifikansi sebesar 0,000 dan nilai beta 0,208 dan setelah dimediasi nilai beta mengalami penurunan. Dengan demikian hipotesis ini diterima. 


\section{$\mathrm{H}_{3} \quad$ kualitas laporan keuangan memediasi hubungan konsentrasi kepemilikan dan struktur modal}

Variabel konsentrasi kepemilikan setelah dimediasi oleh kualitas laporan keuangan memiliki nilai signifikansi 0,258 dan beta $-0,030$ (nilai beta mengalami penurunan) menandakan bahwa variabel tersebut memiliki pengaruh negatif yang tidak signifikan terhadap struktur modal. Hal ini menunjukkan bahwa kualitas laporan keuangan sebagai variabel mediasi, memediasi sempurna hubungan variabel konsentrasi kepemilikan terhadap struktur modal, dari yang sebelum memasukkan variabel mediasi, konsentrasi kepemilikan memiliki nilai signifikansi sebesar 0,004 dan nilai beta -0,074, setelah dimediasi nilai beta mengalami penurunan. Dengan demikian hipotesis ini diterima.

\section{$\mathrm{H}_{4}$ kualitas laporan keuangan memediasi hubungan kepemilikan manajerial dan struktur modal}

Kepemilikan manajerial setelah dimediasi oleh kualitas laporan keuangan memiliki nilai signifikansi 0,000 dan beta $-0,242$ (nilai beta mengalami penurunan) menandakan bahwa variabel tersebut memiliki pengaruh negatif yang signifikan terhadap struktur modal. Hal ini menunjukkan bahwa kualitas laporan keuangan sebagai variabel mediasi, memediasi hubungan kepemilikan manajerial terhadap struktur modal, dari yang sebelum memasukkan variabel mediasi, kepemilikan manajerial memiliki nilai signifikansi sebesar 0,000 dan nilai beta $-0,304$ dan sesudah dimediasi nilai beta mengalami penurunan. Dengan demikian hipotesis ini diterima.

\section{Kualitas laporan keuangan memediasi hubungan profitabilitas dan struktur modal}

Profitabilitas setelah dimediasi oleh kualitas laporan keuangan memiliki nilai signifikansi 0,000 dan beta $-1,220$ (nilai beta mengalami peningkatan) menandakan bahwa variabel tersebut memiliki pengaruh negatif yang signifikan terhadap struktur modal. Namun kualitas laporan keuangan sebagai variabel mediasi, tidak memediasi hubungan profitabilitas terhadap struktur modal, sebelum memasukkan variabel mediasi, profitabilitas memiliki nilai signifikansi sebesar 0,000 dan nilai beta $-1,058$ sesudah dimediasi nilai beta mengalami peningkatan.

\section{Hasil Uji Koefisien Determinasi}

Hasil Uji Koefisien Determinasi dari model regresi disajikan dalam Tabel 7. Koefisien determinasi menunjukkan bahwa nilai sebesar 0,342 yang mengindikasikan bahwa variabel independen dalam penelitian ini (ukuran dewan, komposisi dewan, konsentrasi kepemilikan, kepemilikan managerial dan profitabilitas) dapat menjelaskan variabel dependen rasio hutang sebesar $34,2 \%$, sedangkan $65,8 \%$ dijelaskan oleh faktor lain yang tidak disebutkan dalam model

Tabel 7. Hasil Uji Koefisien Determinasi

\begin{tabular}{ccr}
\hline Variable Dependent & Adjusted R Square & Std. error \\
\hline Debt To Ratio & 0,342 & 0,12249 \\
\hline Sumber: Data Sekunder diolah (2016) &
\end{tabular}

\section{DISKUSI DAN KESIMPULAN}

Hasil penelitian menunjukkan bahwa ukuran dewan memiliki arah hubungan negatif yang tidak signifikan terhadap struktur modal. Hal ini berarti ukuran dewan direksi tidak memiliki pengaruh yang signifikan bagi perusahaan dalam mengatur pendanaan demi terciptanya keputusan struktur modal yang baik. Hasil penelitian ini konsisten dengan penelitian terdahulu oleh Corsi dan Prencipe (2015), Marand (2015), Boochani dan Moradi (2012), Hussainey dan Aljifri (2012), Mousavi et al (2012), Rehman et al (2010). Sedangkan komposisi dewan independen memiliki hubungan positif yang signifikan terhadap struktur modal. Hal ini berarti semakin banyak jumlah anggota dewan komisaris independen maka semakin tinggi pula kecenderungan untuk mengejar kebijakan hutang yang tinggi. Jumlah dewan komisaris independen yang tinggi memonitor manajemen lebih aktif dan memaksa manajemen untuk memilih tindakan-tindakan yang memaksimalkan kekayaan pemegang saham sehingga dapat menambah sumber pendanaan perusahaan dari pihak luar yang dapat meningkatkan rasio hutang. Hasil penelitian ini konsisten dengan penelitian yang dilakukan oleh Jaradat (2015), Sheikh dan Wang (2012), Ganiyu dan Abiodun (2012), Kajananthan (2012), Boochani dan Moradi (2015), Agyei dan Owusu (2014).

Konsentrasi kepemilikan memiliki hubungan negatif dan signifikan terhadap struktur modal. Hasil penelitian ini menunjukkan bahwa blockholders yang besar cenderung mengurangi penggunaan hutang dan cenderung memakai ekuitas untuk investasi modal. Kepemilikan manajerial juga memiliki hubungan 
yang negatif dan signifikan terhadap struktur modal. Semakin besar kepemilikan manajerial akan menyelaraskan kepentingan manajer dan kepentingan pemegang saham luar serta mengurangi proporsi hutang untuk mengurangi masalah keagenan. Pihak manajerial akan cenderung untuk menghindari penggunaan hutang dan menjadi risk-averse. Hal ini dilakukan untuk menghindari terjadinya risiko kebangkrutan. Hasil penelitian ini didukung dengan penelitian yang dilakukan oleh Corsi dan Prencipe (2015), Akbari dan Rahmani (2013), Sheikh dan Wang (2012). Demikian juga profitabilitas memiliki hubungan yang negatif dan signifikan terhadap struktur modal. Perusahaan yang memiliki tingkat profitabilitas yang tinggi tidak membutuhkan pendanaan yang berasal dari pinjaman hutang, karena mereka dapat menggunakan dana yang dihasilkan oleh internal perusahaan itu sendiri yaitu laba perusahaan dalam bentuk lab ditahan. Hasil dari pengujian ini konsisten dengan penelitian yang dilakukan oleh Jaradat (2015), Ganiyu dan Abiodun (2012), Boochani dan Moradi (2015), Akbari dan Rahmani (2013), Sheikh dan Wang (2012).

Hasil penelitian menunjukkan ukuran dewan setelah dimediasi oleh kualitas laporan keuangan memiliki pengaruh negatif yang signifikan terhadap struktur modal. Kualitas laporan keuangan tidak memediasi hubungan variabel ukuran dewan terhadap struktur modal. Sebelum memasukkan variabel mediasi ukuran dewan tidak memiliki pengaruh signifikan terhadap struktur modal, walaupun memiliki pengaruh signifikan terhadap struktur modal setelah dimediasi. Hasil penelitian ini tidak konsisten dengan penelitian yang dilakukan oleh Sariman et al (2013).

Komposisi dewan independen setelah dimediasi oleh kualitas laporan keuangan memiliki hubungan yang positif dan signifikan terhadap struktur modal. Kualitas laporan keuangan memediasi parsial hubungan komposisi dewan independen terhadap struktur modal. Sebelum memasukkan variabel mediasi komposisi dewan independen memiliki hubungan positif dan signifikan terhadap struktur modal serta angka koefisien regresi sebesar 0,208 . Namun setelah dimediasi angka koefisien regresi mengalami penurunan menjadi 0,194.

Konsentrasi kepemilikan setelah dimediasi oleh kualitas laporan keuangan memiliki pengaruh negatif yang tidak signifikan terhadap struktur modal. Kualitas laporan keuangan memediasi sempurna hubungan variabel konsentrasi kepemilikan terhadap struktur modal. Sebelum memasukkan variabel mediasi, konsentrasi kepemilikan memiliki hubungan yang negatif dan signifikan terhadap struktur modal. Namun setelah dimediasi menjadi tidak ada pengaruh terhadap struktur modal dan nilai beta mengalami penurunan.

Kepemilikan manajerial setelah dimediasi oleh kualitas laporan keuangan memiliki pengaruh negatif yang signifikan terhadap struktur modal. Kualitas laporan keuangan memediasi hubungan kepemilikan manajerial terhadap struktur modal. Sebelum memasukkan variabel mediasi, kepemilikan manajerial memiliki hubungan yang negatif dan signifikan terhadap struktur modal dan setelah dimediasi nilai beta mengalami penurunan. Profitabilitas setelah dimediasi oleh kualitas laporan keuangan memiliki pengaruh negatif yang signifikan terhadap struktur modal. Hal ini menunjukkan bahwa kualitas laporan keuangan tidak memediasi hubungan antara profitabilitas terhadap struktur modal. Sebelum memasukkan variabel mediasi profitabilitas memiliki hubungan yang negatif dan signifikan terhadap struktur modal. Namun setelah dimediasi angka pada koefisien regresi mengalami peningkatan.

Penelitian berikutnya dapat menambahkan variabel independen lainnya yang dapat mempengaruhi rasio total hutang dan rasio hutang jangka panjang dan menggunakan variabel mediasi yang lainnya seperti investment opportunity.

\section{DAFTAR PUSTAKA}

Agyei, A., \& Owusu, A.R. (2014). The effect of ownership structure and corporate governance on capital structure of Ghanaian listed manufacturing companies. Internasional Journal of Academic Research in Accounting, Finance, and Management Sciences, 4(1), 109-118.

Ahmadpour, A., Samimi, A.J., \& Golmohammadi, H. (2012). Corporate governance and capital structure: Evidence from Tehran Stock Exchange. Middle-East Journal of Scientific Research, 11(4), 531-535.

Akbari, M. A., \& Rahmani, S. (2013). Does corporate governance and ownership structure influence capital structure: Empirical evidence from Iran. World of Sciences Journal, 11(4), 531-535. 
Baron, R.M., \& Kenny, D.A. (1986). The moderator-mediator variable distinction in social psychological research: Conceptual, strategic, and statistical considerations. Journal of Personality and Social Psychology. 51(6), 11731182.

Boochani, K., \&Moradi.F (2015).Investigation Effect of Corporate Governance on Capital Structure of Listed Companies in Tehran Stock Exchange. Internasional Journal of Review in Life Sciences, 5(3), 110-117.

Claessens, S., \& Fan, J. P. (2002). Corporate governance in Asia: A survey. International Review of Finance, 3(2), 71-103.

Corsi, C., \& Prencipe, A. (2015). Corporate Governance and Capital Structure Interactions in New Technology-Based Firms. The Effects of Ownership Structure and Board of Directors on Firm's Leverage. American Internasional Journal of Contemporary Research, 5(5), 118 - 128.

Fan, Y. (2005). Accounting transparency and the term structure of credit spreads. 75(1), 53-84. Journal of financial economics,

Ganiyu, Y.O., \& Abiodun, B.Y. (2012). The Impact of Corporate Governance on Capital Structure Decision of Nigerian Firms, Research Journal in Organizational Psychology \& Educational Studies, 1(2), 121-128.

Ghabayen, M. A. (2012). Board characteristics and firm performance: Case of Saudi Arabia. International Journal of Accounting and Financial Reporting. 2(2): 168-200.

Gill, A., Biger, N., Mand, H. S., \& Charul, S. (2012). Corporate Governance and Capital Structure of Small Business Service Firms in India. International Journal of Economics and Finance, 4(8), 83-92.

Gitman, L.J., \& Zutter , C. J. (2012). Principles of managerial finance: Global Edition, 13th edition. United States: Pearson.

Graham, J. R., Hazarika, S., \& Narasimhan, K. (2011). Corporate Governance, Debt, and Investment Policy during the Great Depression. Management Science, 57(12), 2083-2100.
Hasan, A. \& Butt, S. A. (2009). Impact of ownership structure and corporate governance on capital structure of Pakistani listed companies. International Journal of Business \& Management, 4(2), 50-57.

Heng, T.B., Azrbaijani, S., \& San, O.T. (2012). Board of Directors and Capital Structure: Evidence from Leading Malaysian Companies.Canadian Center of Science and Education, 8(3), 123-136.

Hussainey, K., \&Aljifri, K. (2012). Corporate governance mechanisms and capital structure in UAE. Journal of Applied Accounting Research, 13(2), 145-160.

Indriantoro, N., \& Supomo, B. (2002). Metodologi penelitian bisnis. Edisi Pertama. Yogyakarta: BPFE.

Jaradat, M.S. (2015). Corporate governance practices and capital structure: A study with special reference to board size, board gender, outside director, and CEO duality. Internasional Journal of Economics, Commerce and Management, 3(5), 264 - 273.

Jensen, M. C., \& Meckling, W. H. (1976). Theory of the firm: managerial behavior , agency cost and capital structures. Journal of Financial Economics, 3(4), 305-360.

Jensen, M. (1986). Agency cost of free cash flow, corporate finance, and takeovers. Corporate Finance, and Takeovers. American Economic Review, 76(2), 323329.

Jiraporn, P., Kim, J.-C., Kim, Y. S., \& Kitsabunnarat, P. (2012). Capital structure and corporate governance quality: Evidence from the Institutional Shareholder Services (ISS). International Review of Economics \& Finance, 22(1), 208-221.

Johnson,J.L., Daily,C.M., \& Ellstrand, A.E. (1996). Boards of directors: a review and research agenda. Journal of Management, 22(3), 409-438.

Kajananthan, R. (2012). Effect Corporate Governance on Capital Structure: Case of the Srilankan Listed Manufacturing Companies. Journal of Arts, Science \& Commerce, 3, 4(1), 63-71.

Kassim, A.A.Md., Ishak, Z., \& Manaf, N.A.A. (2013). Board Effectiveness and Company Performance: Assessing the Mediating Role of Capital 
Structure Decisions. International Journal of Business and Society, 14(2), 319-338.

Khan, I., \& Wasim, F. (2016). Impact of corporate governance and ownership structure on capital structure. Internasional Journal of Management Sciences and Business Research, 3(11), 119-133.

Marand, A.A., Shabani, M., \& Hnema, M. (2014). The relationship between the corporate governance mechanisms and the capital structure of holding companies. Indian Journal of Fundamental and Applied Life Sciences, 4(1), 1212-1218.

Modigliani, F and Miller, M.H., (1958). The Cost of Capital, Corporation Finance and the Theory of Investment. American Economic Review, 48, 261-97.

Mirza, D. (2015). Capital structure determinants in Europe: The effect of profitability and the moderating role of firm size. The Faculty of Behavioural, Management and Social Sciences.

Mousavi, Z., Jari, A., \& Aliahmadi, S. (2012). The Evaluation of Corporate Governance Monitoring Mechanisms on Capital Structure in Tehran Stock Exchange. International Journal of Business and Social Science, 3(1), 192-197.

Myers, S. C. (1984). The capital structure puzzle. The Journal of Finance, 39(3), 574-592.

Myers, S. C. (2001). Capital structure. The Journal of Economic Perspectives, 15(2), 81-102.

Rehman, M.A.U., Rehman , R. U., \& Raoof , A. (2010). Does corporate governance lead to a change in the capital structure? American Journal of Social and Management Sciences, 1(2), 191-195.

Rezaei, F., Ghorbani, B., \& Yaghoubi, A. (2012). The effect of corporate governance on enterprises finance structure. Interdisciplinary Journal of Contemporary Research in Business, 3(11), 187-202.

Santoso, S. (2014). Statistik Parametik: Konsep dan Aplikasi dengan SPSS. Jakarta: Elex Media Komputindo.

Sariman, A.S.B., Ali, A., \& Nor. M.H.M. (2013). The mediating effects of financial reporting quality on audit committee quality and capital structure in Omani
firms.Internasional Journal of Finance and Accounting, 2(8), 452-458.

Sheikh, N.A., \& Wang, Z. (2012). Effects of corporate governance on capital structure: empirical evidence from Pakistan, Huazhong University of Science and Technology, China, 12(5), 629-641.

Stretcher, R., \& Johnson, S. (2011). Capital structure: professional management guidance. Managerial Finance, 37(8), 788-804.

Subramanyam, K.R., \& Wild, J.J. (2010). Analisis Laporan Keuangan. Jakarta: Salemba Empat.

Sugiyono. (2009). Metode Penelitian Kuantitatif, Kualitatif dan $R \& D$. Bandung: Alfabeta.

Vakilifard, H. R., Gerayli, M. S., Yanesari, A. M., \& Ma'atoofi, A. R. (2011). Effect of Corporate Governance on Capital Structure: Case of the Iranian Listed Firms. European Journal of Economics, Finance and Administrative Sciences, 35, 165-172.

Velnampy, T., \& Niresh, J.A. (2012).The relationship between capital structure and profitability.Global Journal of Management and Business Research. 12(13). 66-74

Wen, Y., Rwegasira, K., \& Bilderbeek, J. (2002). Corporate governance and capital structure decisions of the Chinese listed firms. Corporate Governance: An International Review, 10(2), 75-83.

Zabri, S.M., Yusoff, W.F.W., Ramin, A.K., \& Ling, K.S.S. (2016). Corporate governance practices and firm's capital structure. International Business Management. 10(17). 3973-3981.

Bambang, 2006.

http://www.antaranews.com/berita/3874

3/komisaris-bongkar-dugaan-manipulasilaporan-keuangan

Syahrul, 2003.

https://bisnis.tempo.co/read/news/2003/0 3/18/0566701/bej-anggap-kasus-laporankeuangan-bank-lippo-selesai.

Triyanto, 2011.

http://economy.okezone.com/read/2011/ 01/04/278/410110/bapepam-lk-periksakatarina-utama. 
Jurnal Manajemen Maranatha — Vol. 16 Nomor 2, Mei (2017) 